\title{
THE GROWING REFUGEE CRISIS IN THE SOVIET UNION - THE PLIGHT OF ARMENIANS
}

\author{
Tanya Basok \\ Department of Sociology and Anthropology \\ University of Windsor, Ontario \\ and
}

University of Windsor, Ontario

\author{
Marina Makarova, \\ Joumalist, Leningrad, \\ U.S.S.R.
}

The process of democratization in the Soviet Union provoked the eruption of regional and ethnic conflicts which had hitherto remained dormant. In several Soviet republics nationalist movements emerged demanding regional autonomy. These struggles intensified existing ethnic tensions. The conflict between Azeris and Armenians in Azerbaijan is one such case.

\section{...And Then There Was None}

"We lived in constant fear hiding our children in the basement", testified Zhanna Tsaturova, a mother of six children from Baku. "Then on December 5,1988 a bunch of people (real animals) started breaking windows in the houses inhabited by Armenians"

No one bothered me until June 1989", stated a 59-year-old Arkadii Babayan from Baku, 'but in June they started making threats by phone, Then they dropped threatening notes in $\mathrm{my}$ mail box telling me to leave; otherwise they threatened to kill or mutilate me."

These statements could have come from any other Armenians forced to leave Azerbaijon. Those who can testify did not suffer the worst fate. Those who cannot, did. They were decapitated, hung toasted in fireor otherwise brutally mundered. Those who managed toescape bear theburden of memories of thebloody days. But memories are not the only thing which torments them; their present situation is just as disconcerting.

\section{The Firet Wave}

There have been three waves of Armenian refugees. The first wave was caused by the genocide in Sumgait. In December 1987, Nagorno-Karabakh demanded autonomy from Azerbaijan, climing that it annexation in 1921 was

illegal, based on falsifications, deceit and threats. It was further argued that Armenians, who made up $30 \%$ of the 175,000 population of NagornoKarabakh, weredeprived of their cultural roots and political rights. The government of Azerbaijan fiatly rejected the claim. Tensions mounted and on February 28 Azeris started Amenian pogroms in Sumgait. According to some estimates more than a hundred were brutally massacred. Corpses were often

\section{The second wave of Armenian refugees consisted of victims of both human violence and natural disaster. But the earthquake ooershadowed pogroms in Azerbaijan by far.}

burned. Gorbachev sent the troops to pacify the raging mobs. A state of slege was declared.

Some Armenians fled to other cities then but they were not numerous. In fact, no one even noticed them. They demanded no assistance and settled on their own.

Hostilities between Axeris and Armenians culminated once again in November 1988. Cultural and economic ties between Nagorno-Karabakh and Armenia were growing. Demands for the right to self-determination were getting stronger and presented a real threat to Moscow. According to Igor
Babanov, an active member of the Armenian community in Leningrad and a writer, ethnic violence against Armenians was condoned by Gorbachev's Central Committee. New massacres provoked another wave of refugees.

Shortly afterwards yet another misfortune beset the Armenian people. On December 7, 1988 an earthquake devastated Armenia taking between 35,000 and 50,000 lives. Their houses destroyed, empty-handed people ran to Moscow and Leningrad hoping that the Kremlin was not going to ignore their suffering.

\section{The Second Wave}

The second wave of Armenian refugees consisted of victims of both human violenceand naturaldisaster. But the earthquake overshadowed pogroms in Azerbaifan by far. The sight of lightly iresed people in the middle of the winter touched people's hearts. The public response was truly remarkable. The Armeninncommunity, organised around the Church, cooperated withmembers of other voluntary groups in creating an ad hoc committee. People donated money, blankets, clothes; they offered their already overerowded apartments. Many Moscovites and Leningradians took the Armenian tragedy very close to their hearts. One whe Tamara Tronova, a young widow with two childen. Her phonenumber wregtven to all Armenian refugees as a contact number in Leningrad. The young unemployed woman suddenly found herself very busy. Her only reward was the satisfaction from having helped some people in need. Refugees from Baku also benefited from the aidextended to victions of the earthquake. 
Armenians were sent to recreation centres just outside Leningrad and Moscow. There they received free food. The earthquake emergency funds were used to aid the refugees. Overall, the presence of the earthquake victims received a sympathetic response. This was not quite the case with the Armenians from Baku.

Zhanna Tseturova and her family from Baku were settled in a recreation centre near Leningrad. A few days later

\section{Armenian Refugee \\ (Photo: Alexander Belenkii)}

50 Amenian families whose houses had been devastated by the earthquake were moved there as well. Then two women came by in a black Volga (an official car) and told her to move out. "They told me and my six children to go back to Baku. Otherwisel would bekicked out. I started crying", writes Zhanna in her testimony.

Zhanna's misfortunes continued. To get to school her children had to walk a long distance through the forest. One day one of her daughters was assauited on the way there. Fortunately for her, some people passing by scared the offender.

And as if this was not enough, their emergency aid wascut off. Her husband's salary earned in a local collective farm was not sufficient. The family was sturving. One of her daughters went to theldtchen to get a plece of bread. Shecut off two of her fingers in a bread-slicer. (She had studied piano for three years in a conservatory in Baku.)

\section{The Third Wave}

But the most problematic was the thind wave of 300,000 Armenian refugees thrown out of Baku in January, 1990. The refugee flow followed the massacre of 56 Armenians in fourdays between January 13 and 16.

Even during the war I was not as sared as I was on January 13, 1990 in Baku. Then I could defend myself with a weapon whereas now I felt entirely helpless", writes a 69-year-old medical doctor, Gaarlk Karapetyan in her letter

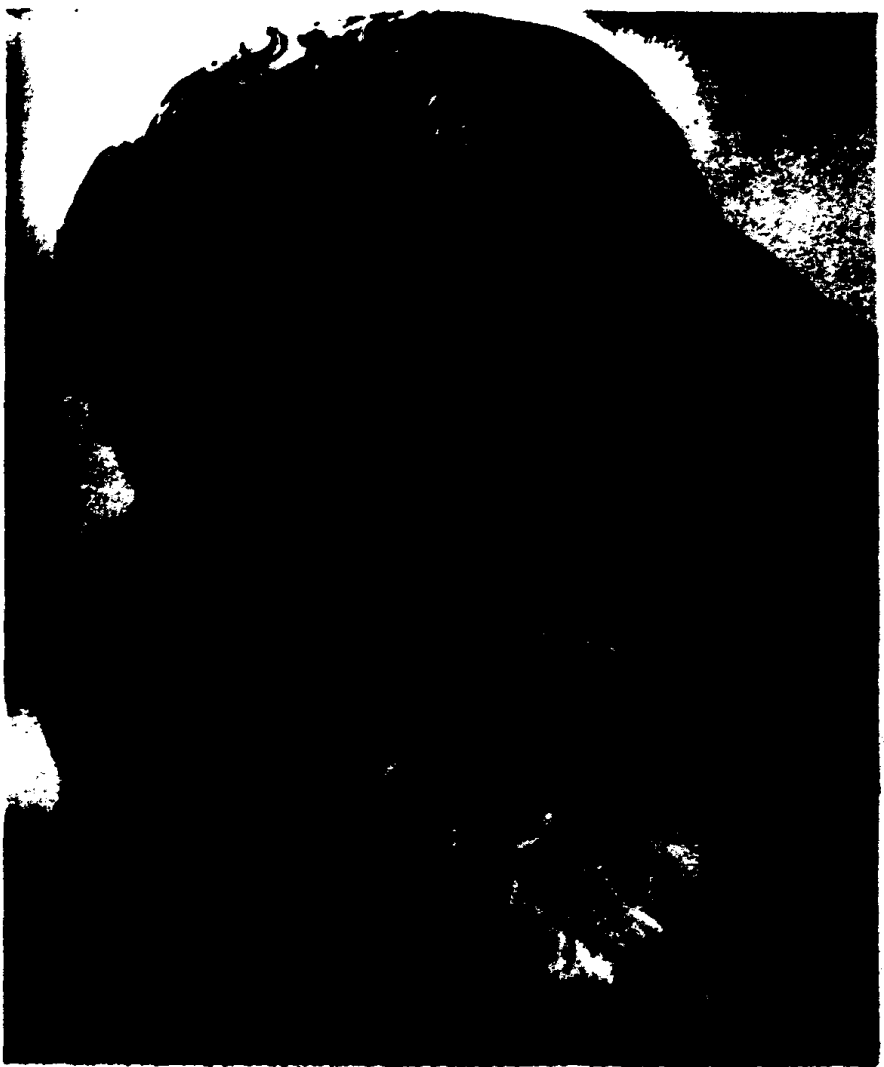

addressed to the Amenian Assembly of America.

There is one interpretation which puts the blame for violence on "erazt". the name given to Azeri migrants from Armenia. By February 1990,90,000 Azerto had moved to Baku. The government failed to solve their housing problem. They took the initiative into their own hands and started invading and robbing apartments occupled by Armenians.

But there is also another version. Appeals to violence are traced to the December 1989 issue of "Azadlylk" a newspaper of the People's Front of Azerbalfan (NFA). Maseacres followed NFA'smeetingsand demonstrationsheld in eariy January. NRA leadervdemanded regional autonomy. Appeals to masascre Armenians were diso heard. Although "eraxi" attacked Armenians, very few of them actually, got the invaded apartments. Rumoursare that NPA sold them or distributed them among themselves By January 26, not a single Armenian was left in Baku.

\section{Welcome to Step-Notheriand}

It would seem logical that all refugees from Aserbaljan would move to Armenia. Wry didn't they? First, the earthquake left 500,000 people without shelter. Second, transportation of food. fuel and construction materials was blocked by Azerbaijan thus making reconstruction of the devastated area Neariy imposible. Thind, there is a language barrier between Russlanspeaking Armenians from Baku and Armentan-opeaking reaidents of Brevan. And finally, many refugees blame Armenian nationaliate for having provoked the conflict in which Armenlars realding in Azerbalfan feil victim.

Consequently some 40,000 - 60,000 Armentan refugees arrived in Moscow and over 3,000 Amentan came to Leningred in need of shelter, food and work. They were given a token donation of 100 rubles incach and 200 rubles worth of clothes. A hundred rubles can get one a bachelor apartment for onemonthl And shelter was not for everyone. For foer 